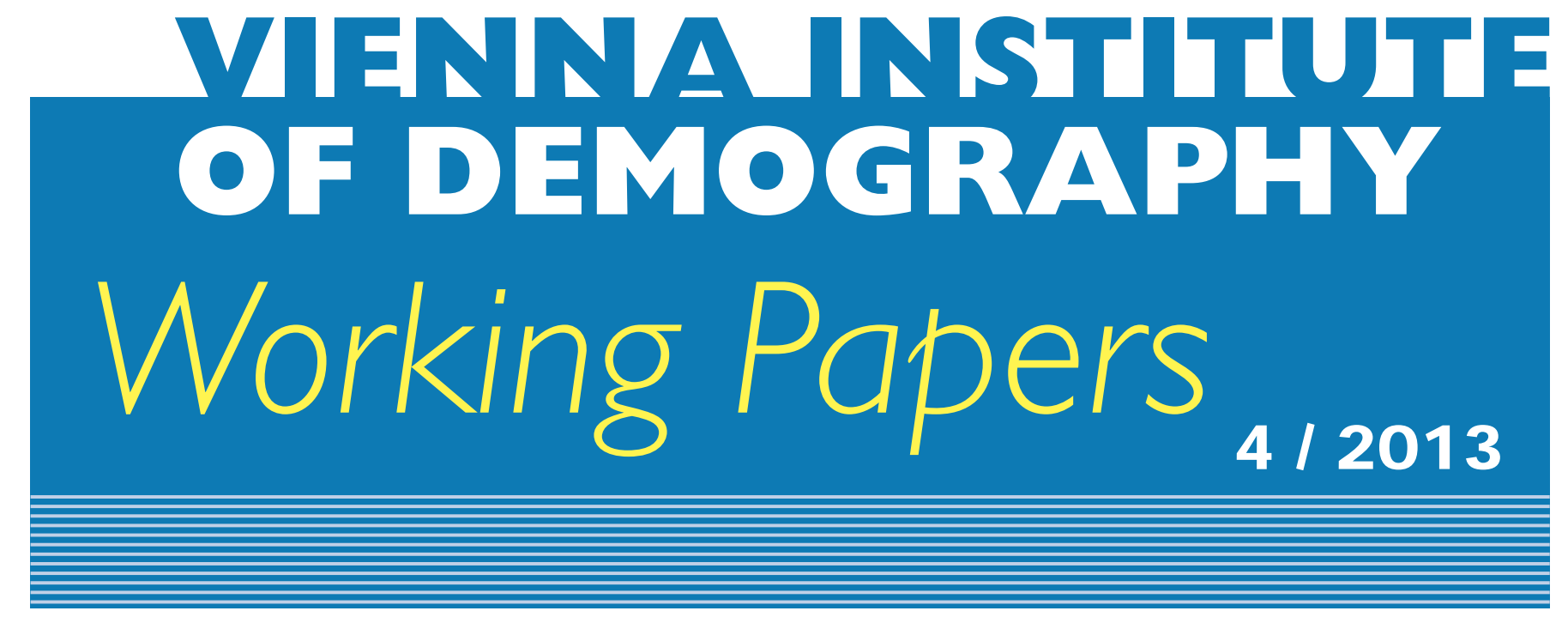

Ethan Sharygin

\title{
The Carbon Cost of an Educated Future: A Consumer Lifestyle Approach
}

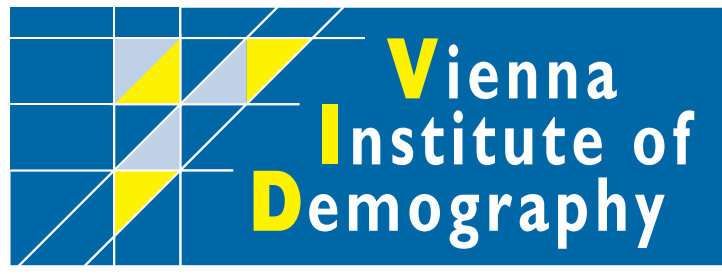

Vienna Institute of Demography Austrian Academy of Sciences

Wohllebengasse 12-14

A-I 040 Vienna $\cdot$ Austria

E-Mail:vid@oeaw.ac.at

Website: www.oeaw.ac.at/vid 


\begin{abstract}
Demographic and economic growth will account for most of the anticipated growth in greenhouse gas (GHG) emissions in the next century. Education is associated with development, and the world population in the near future is likely to be significantly better educated than today. Previous studies of household energy demand and associated emissions have not directly considered the consequences of a more educated population. In this study, I estimate the energy intensity of consumption dollars and the total impact of households according to their demographic characteristics, with particular attention to differences in spending habits by education and the environmental consequences. I find that education results in fewer emissions per household, holding other household characteristics constant. Each year of education is associated with an average effect in $\mathrm{CO}_{2}$-equivalent $\left(\mathrm{CO}_{2} \mathrm{e}\right)$ emission of $-466 \mathrm{~kg} / \mathrm{yr}$. After controlling for household characteristics, the effect of a year of education is $-163.1 \mathrm{~kg}$ per year. Educated households spend less on home energy and transportation by car, two of the most important sources of household level atmospheric GHG production. They spend relatively more on investment goods, public transport, and other activities which have a low environmental footprint.
\end{abstract}

\title{
Keywords
}

Human capital, environmental impact, household emissions.

\section{Author}

Ethan J. Sharygin is a Visiting Scholar at the Vienna Institute of Demography of the Austrian Academy of Sciences, and a Senior Fellow at the Institute of Health Metrics and Evaluation at the University of Washington.

\section{Acknowledgements}

The author would like to thank Wolfgang Lutz for support during 2013 under the ERC funded "FUTURESOC" project. 


\title{
The Carbon Cost of an Educated Future: A Consumer Lifestyle Approach
}

\author{
Ethan Sharygin
}

\section{Introduction}

Climate change anticipated over the next century as a result of global warming is widely accepted to be of primarily anthropogenic origin, related to our use of fossil fuels (IPCC 2008). Fossil fuels are the most significant source of anthropogenic greenhouse gas (GHG) emissions, and also the engine of economic growth during the last two centuries. Economic growth is a central goal of most nations, and among the consequences of development are greater per capita income and energy demand. Population growth is anticipated as well, with significant implications for energy demand. Demographic and economic growth will account for growth in GHG emissions of 25-90 percent in the next century, depending on changes in fertility, household size, and growth in real income (Bongaarts 1992; MacKellar et al. 1995; Dyson 2005).

Prosperity is a compelling goal, and there are excellent reasons to desire continued economic growth. Under the current technological regime, continued growth appears ecologically unsustainable; however, growth may also be essential for global prosperity. Of utmost importance, then, is identifying ways in which energy demand can be reduced while still allowing growth to be an over-arching goal. Education may be one such pathway; educated societies may produce more technological innovation, lower population growth, and "smarter" consumption that reflects knowledge and concern for environmental impact. Like economic growth, a more educated population is a goal of all nations, developed and developing. If education has an independent effect on behaviours that affect climate change, then it is potentially an important omission from our understanding.

Here, I am concerned specifically with how household energy demand and associated emissions will be affected by a more educated population. Education is associated with development, and the world population in the near future is likely to be significantly better educated (KC et al. 2010; EPDC 2005). I estimate the energy intensity of consumption dollars and the total impact of households according to their demographic characteristics, with particular attention to differences in spending habits by education and the environmental consequences. This includes differences in spending on housing, transportation, durable and non-durable goods, and the associated energy and emissions from production, use, and disposal. This method of accounting has been referred to in various ways; here, I adopt the nomenclature of "consumer lifestyle approach" (CLA) used by Bin and Dowlatabadi (2005).

Section 2 reviews relevant prior research on population, environment, education, and the demographics of household energy use. Section 3 describes the empirical strategy and the sources of data used in the analysis. Section 4 presents the results, and Section 5 concludes with broader implications of the findings and directions for future research. 


\section{Background and Related Literature}

\subsection{Population and Environment}

Population has long been recognized as a driver of energy use. An influential thread within the environmentalist movement began to express renewed interest in the Malthusian hypothesis - that the growth of population must out-pace the growth of resources, with tragic consequences. In 1948 two important books on this topic appeared, Our Plundered Planet and The Road to Survival (Osborn 1948; Vogt 1948). Both authors critiqued environmental exploitation and overpopulation, were immensely influential in their time, and came to inform the arguments of ecologists and environmentalists of the next generation, including P. R. Ehrlich and others (Robertson 2012; Desrochers and Hoffbauer 2009).

Population has been explicitly used as a scale variable to calculate environmental impact since the early 1970 s at latest, with the advent of the I=PAT identity, which defines environmental impact as a function of population, income, and production technology (Ehrlich and Holdren 1971; Commoner 1972). ${ }^{1}$ The first treatments of population assumed that emissions increase linearly with population growth, but subsequent research has shown that approximation to be insufficient in long-run projections, as additional characteristics such as age structure and household size can have a significant effect.

In the wake of the discussions during the 1970s and 1980s, much more has been learned about the role of population characteristics on energy demand and emissions. MacKellar et al. (1995) found that smaller household size is associated with greater per capita energy demand - an important result, considering that later marriage, lower fertility, and changing social norms regarding the family have tended to reduce average household size in developed countries. O'Neill and Chen (2002) expanded on this analysis by considering age as well as household size, and found that there is a distinct age pattern of energy consumption that may translate into more energy use in the U.S. as the mean age of the population rises in the future. Zagheni (2011) conducted a thorough and refined analysis of direct and indirect energy demand which confirms that aging is likely to cause small but significant increases in GHG emissions of U.S. households. The robustness of these results has led to major efforts to incorporate demographic change into mainstream global emissions models (Dalton et al. 2008; O’Neill et al. 2010).

Urbanization is another important contributor to variation in the relationship between population and impact. The effect of urbanization depends in turn on the level of economic development (Pariakh and Shukla 1995; Martinez-Zarzoso 2008; Cole and Neumayer 2005). Less developed countries are likely to experience growth in emissions as populations move to the city, due to the relatively low energy intensity of the rural economy. Wealthier countries, on the other hand, see a modest reduction in emissions with further urbanization. In the U.S., the average difference in direct and indirect energy

\footnotetext{
${ }^{1}$ A discussion of the $\mathrm{I}=\mathrm{PAT}$ formulation is beyond the scope of this paper, but interested readers may refer to O’Neill and Chen (2002).
} 
demand between suburban or rural households and urban households is approximately 20 percent (Shammin et al. 2010).

\subsection{Households and Energy Demand}

Households, and the consumers within them, are responsible for the lion's share of the total energy production and use in the U.S., through direct sources (such as combustion of fuel for heating and transportation) and indirect energy associated with demand for products and services. Somewhere between 70 percent (Shammin et al. 2010) and 85 percent (Bin and Dowlatabadi 2005) of total domestic energy demand and emissions can be explained by demands for goods and services embedded in lifestyle choices.

The analysis of emissions according to the households whose demand created them has been referred to as the "consumer lifestyle approach" (CLA) or "consumption based approach" (Bin and Dowlatabadi 2005; Wiedmann 2009). CLA and similar approaches have been used to estimate the environmental footprint of households in Australia (Lenzen 1998), India (Pachauri and Spreng 2002), China (Wei et al. 2007; Golley et al. 2008), and across Europe (Weber and Perrels 2000; Reinders et al. 2003; Hertwich and Peters 2009). Together, these findings have strengthened the case that the final demand of households is a compelling perspective for measuring an economy's environmental impact.

\section{Data and Methods}

In the subsequent sections, I estimate energy and GHG impacts of households by multiplying expenses in dollars by the carbon intensity $\left(\mathrm{kg} \mathrm{CO}_{2} / \$\right)$ or energy intensity $(\mathrm{TJ} / \$)$ of goods and services. All expenditures less taxes and cash transfers are included, and all sources of income (after taxes) are included. ${ }^{2}$ Total household emissions $E$ is calculated by $E=\sum_{i=1}^{n} \rho_{i} Y_{i}$, where $\rho$ refers to the intensity coefficient, $Y$ is the total expenditure in the expenditure category $i$. I relate total emissions to expenditures by the following nonlinear model, following Herendeen et al. (1981); Pachauri (2004) and Lenzen et al. (2006):

$$
E=K \times Y^{\alpha}
$$

Where $K$ is a constant and $\alpha$ represents a coefficient on log income. Rewritten as a $\log$-linear model with multiple predictors $X$ and error term $\varepsilon$, Eq. 1 becomes:

$$
\ln E=\ln K+\alpha \ln Y+\beta_{1} X_{1}+\cdots \beta_{n} X_{n}+\varepsilon
$$

The model is executed as a generalized linear model with log link function, avoiding the introduction of transformation bias during the estimation.

\footnotetext{
2 Cash transfers between households are excluded. Although tax-funded public services have an environmental footprint, taxes are excluded from expenditures because they are not very indicative of consumer lifestyle choices.
} 


\subsection{Carbon Intensity of Demand}

The energy and carbon intensity of goods and services is calculated from input-output matrices of the U.S. economy produced by the Bureau of Economic Analysis (BEA) of the U.S. Department of Commerce and extensively adapted by the Green Development Initiative (GDI) team at Carnegie Mellon University (2008). The BEA matrices describe the economic activity generated in other industries for a given level of demand in dollars to a single industry, and these are modified and added to by GDI to provide estimated energy use and environmental externalities associated with a given amount of economic demand for a good or service over its entire lifecycle, including the production, wholesale, retail, transportation, use, and disposal phases. ${ }^{3}$

Environmental impact can be classified into two categories: indirect and direct. Direct impacts include demand for primary energy, in the form of electricity, natural gas, gasoline, and other fuels. Indirect impacts include non-energy goods and services, such as haircuts, apparel, and telephone service. Intensities are calculated on the basis of final purchaser price for a set of 65 categories of goods and services: 5 direct and the rest indirect. To generate the set of intensities in the form of the desired units of impact per dollar of final demand, I calculate the Leontief inverse of the relevant input-output matrices produced by GDI.

For direct impacts, I estimate the energy expenditure and GHG emissions from data published by the Energy Information Administration (EIA) of the US Department of Energy. For products such as gasoline, GDI matrices include energy and emissions associated with production, transportation, and sale of gasoline, but not the carbon released by combustion. The EIA provides historical information on the price of energy goods, as well as their energy content and carbon density. Where applicable, I incorporate these data as annual averages at the state level. GHG emissions associated with electricity production, for example, varies across states and over time, and these variations are included in the calculations used in this paper. The direct energy data for fuels are summarized in Table 5 in the appendix. Associating emissions from direct consumption of energy contributes to the completeness and accuracy of CLA estimates, but this paper is the first to estimate direct impacts from a consumption survey directly. An advantage of this approach is that direct energy use can be studied across a fuller set of household characteristics than, for example, exist in alternative datasets such as the Residential Energy Consumption Survey (RECS).

Indirect impacts from consumption are calculated using intensity coefficients described above. This process involves several steps: dividing expenditures in categories such as clothing or car leasing into BLS-standard commodity codes ("UCC"); converting

\footnotetext{
${ }^{3}$ There are two exceptions to this rule. First, GDI does not include impacts from the use phase of direct energy goods besides electricity. Second, the GDI electricity model does not account for regional variation in the carbon intensity of electricity production; the efficiency and carbon intensity of electricity production varies greatly by region. I opt to modify the GDI-calculated intensity coefficients by a factor equal to the ratio of the state-specific direct use coefficient to the national average coefficient. Additionally, I directly estimate the impact during the use phase of gasoline, natural gas, and fuel oil and add these to the GDI results when they are missing.
} 
these to BEA-standard commodity codes ("PCE"); converting these into BEA industry codes that match those in the GDI data, and finally calculating the Leontief inverse for the activity in the set of industries activated by final demand for the goods or service. These steps are illustrated in Table 1 for purchases of alcohol, with the final step simplified by summing the impact within each industry for all the industries activated by the purchase. Purchases of alcohol include of purchases of beer, wine, and other alcoholic beverages; these correspond to three PCE items: beer, wine, and spirits, which represented 45, 43, and 12 percent, respectively, of total spending on alcohol in the consumption survey. The BEA provides a bridge between commodity and industry codes, usually with several industry codes for each commodity. In this case, wine and beer are 100 percent represented by the activities of wineries and breweries, but only 95 percent of purchases of spirits accrue to distilleries, with 5 percent of the final demand for spirits going to food manufacturing.

Table 1: Example crosswalk between CES survey and 10 model codes, US 1997-2002

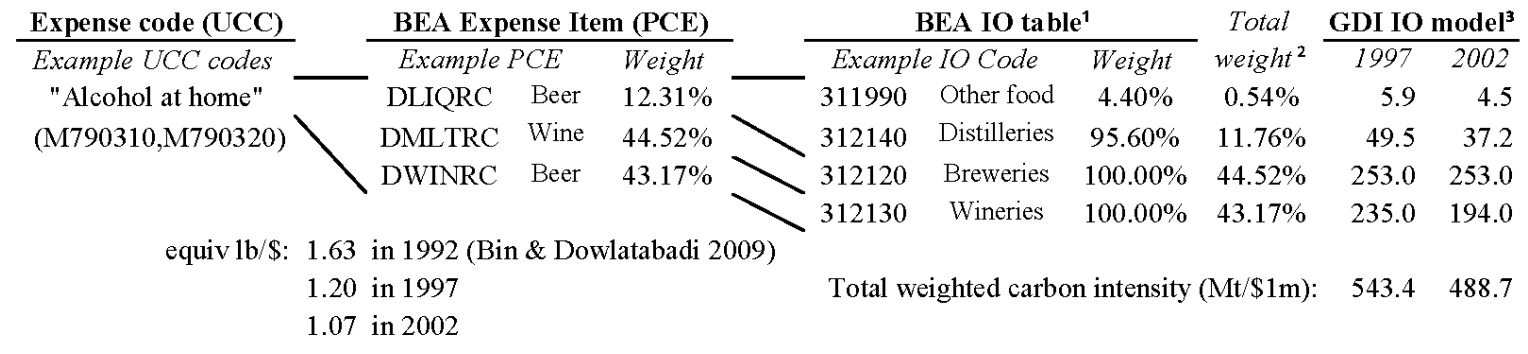

Notes: ${ }^{1}$ "Alcohol at home" has identical IO codes in 1997 and 2002. ${ }^{2}$ Net weight represents share of value in UCC category to assign to activity in each industry. ${ }^{3}$ Leontief inverse of total CO2-equivalent output $(\mathrm{Mt} / \$ 1 \mathrm{~m})$ estimated from CMU Green Design Institute IO tables, weighted by column 'total weight' (CMU GDI 2008).

Source: Consumer Expenditure Survey, various years; author's calculations.

Over a decade of economic change, GDI produces evidence of significant efficiency gains that have reduced the carbon intensity of alcohol production: the amount of GHG per dollar of activity in this sector has fallen from 1.6lbs of $\mathrm{CO}_{2} \mathrm{e}$ in 1992 (Bin and Dowlatabadi 2005) to just $1.1 \mathrm{lbs}$ in 2002.

\subsection{Consumer Expenditures Survey}

Expenses are calculated from the Consumer Expenditures Survey (CES) for the years 1997 and 2002, coinciding with the years that the GDI has calculated environmental impact matrices from the BEA data. The CES is a nationally representative survey of expenses collected quarterly from households that enrol for four quarters. Microdata from the interview portion of the survey, which contains records of major purchases and expenses at a highly detailed level of categorization, were combined into single annual records by Sabelhaus and Harris (2008) and are hosted on the web by the National Bureau of Economic Research. Expenses are harmonized into 109 consistent categories across years. Additional household characteristics are included from CES microdata that were not included in the original extracts by Sabelhaus and Harris. 
Rent payments or imputed rent are included with other expenditures on housing operations, so that renters and homeowners are treated equally. The sample is restricted to non-student heads of household with no missing income or expenditures data, and who remained in the panel for a full year. Descriptive characteristics of the resulting analytic dataset are reported in Table 2.

Table 2: Demographic and economic characteristics of CES sample, US 1997-2002

\begin{tabular}{lrr}
\hline & \multicolumn{2}{c}{ CES survey year } \\
& \multicolumn{1}{c}{1997} & \multicolumn{1}{c}{2002} \\
\cline { 2 - 3 } Demographic characteristics & & \\
Age (\%) & & \\
15-24 & 51.7 & 6.9 \\
$25-49$ & 20.7 & 24.1 \\
$50-65$ & 21.2 & 19.8 \\
65+ & & \\
Education (\%) & 16.3 & 14.0 \\
$\quad$ Less than high school & 29.8 & 29.2 \\
High school & 27.8 & 29.5 \\
Some college (<4 yrs) & 26.2 & 27.3 \\
College or higher & & \\
Marital status (\%) & 57.0 & 54.6 \\
Currently married & 83.6 & 81.8 \\
$\quad$ Ever married & 2.7 & 2.6 \\
Mean household size & 0.8 & 0.8 \\
Mean children in household & & \\
Economic Characteristics & & \\
Mean income & 43,605 & 53,052 \\
Income after tax & 35,548 & 44,282 \\
Mean expenditure & 37,012 & 43,650 \\
& & \\
N of obs. & 4,950 & 7,351 \\
\hline
\end{tabular}

Notes: Nominal dollars. Survey years include households enrolled during last three quarters of the previous year. Income after taxes excluding transfers. Expenses excluding taxes, fees, and transfers. Totals may not sum due to rounding. Sample restricted to households with non-missing data for all survey waves not headed by students.

BLS average income as tabulated in the CES in 2002 was approximately $\$ 47,000$ after taxes, with expenses totalling $\$ 42,500$. The average household head's age was 48 , and the average size of the consumer unit was 2.5 persons. Income and expenses in this study are calculated differently from official BLS tabulations: I define income and expenditures in such a way that they sum to approximately zero, so that the total flow of post-tax income from all sources through the household is accounted for (cash savings and transfers between households are not counted). Sample restrictions also explain some of 
the deviation between published and estimated values. The samples are demographically congruent.

\subsection{Model Assumptions and Limitations}

Analyses of this type are subject to several important limitations and sources of bias. A limitation of the method used in this paper is the assumption of linear effects of additional expenditures. Since the calculated intensities are constants, the millionth dollar spent in an industry has the same environmental impact as the first. In addition, goods are distinguished only by their type and cost. The model cannot distinguish between identically coded goods, such as a $\$ 500$ watch and ten $\$ 50$ watches, or between a suburban tract house or a city condominium each costing $\$ 250,000$. Errors are also introduced in the process of recoding purchases into a limited number of categories. For example, Sabelhaus and Harris (2008) code bicycles, cameras, and hunting equipment into the same category ("Recreation and sporting equipment"). For the purposes of presentation, these are further aggregated into 12 categories, but this second aggregation step is performed after calculating environmental impact and therefore is not a source of additional error. The detailed categories within each final category are listed in Table 6 in the appendix.

Foreign and domestic production technology is assumed to be equivalent, so that no distinction is made between the environmental impact of domestically produced and imported goods. This limitation may result in substantially lower or higher estimated indirect emissions, to the extent that U.S. production technology is more or less efficient than countries where imported goods are produced (Weber and Matthews 2007). ${ }^{4}$

\section{Analysis and Discussion}

Table 3 summarizes the emissions profile of the average U.S. household in 1997 and 2002. The average household was responsible for 41.7 megatonnes $(\mathrm{Mt})$ of $\mathrm{CO}_{2} \mathrm{e}$ emissions in 2002, down from $42.8 \mathrm{Mt}$ in $1997 .^{5}$ In 2002 , the total $\mathrm{CO}_{2}$ inventory of the U.S. was approximately 5.825 billion Mt (USDOC ESA 2010). Collectively, emissions generated by consumption of goods and services by 109.3 million U.S. households totalled 4.56 billion Mt, or 78.2 percent of the total U.S. emissions inventory.

The most important source of household emissions is residential energy, which in 2002 accounted for under 4 percent of total household spending but 35 percent of total energy demand an equal share of total emissions. Residential energy includes power and

\footnotetext{
${ }^{4}$ Multi-region input-output models have been developed which include international trade and allow for differences in production technology; these are not used here due to problems with classifications of goods and services across countries, although signs indicate that these models will be ready for deployment very soon (Kanemoto et al. 2011; Peters et al. 2011).

${ }^{5}$ Bin and Dowlatabadi (2005) estimated 54.4Mt per household in 1997, using a 1992 emissions model, producer prices instead of end-user prices, and sources other than the CES for direct energy use. Jones et al. (2008) estimated 23Mt per household for indirect emissions only in 2007 using aggregate data, based on a 1997 emissions model with a significant number of adjustments detailed in their paper.
} 
heating from electricity, natural gas, and fuel oil. Personal transport-mainly gasoline purchases - accounted for a further 3 percent of expenses and 25 percent of emissions. To contrast, household operations (non-power utilities such as phone and water, plus rent, furnishings, and maintenance) is the largest expenditure category at 33 percent of expenses, but only 12 percent of the average household's environmental footprint. In total, direct emissions from the consumption of electricity and liquid fuels totalled $12.1 \mathrm{Mt}$, with the balance of $29.6 \mathrm{Mt}$ attributable to consumption of other goods and services.

Table 3. Mean household emissions (CO2e), US 1997-2002

\begin{tabular}{|c|c|c|}
\hline \multirow[b]{3}{*}{ Direct influences (kg) } & \multicolumn{2}{|c|}{$\begin{array}{l}\text { Mean household } \\
\text { emissions (CO2e) }\end{array}$} \\
\hline & 1997 & 2002 \\
\hline & & \\
\hline Residential energy & 14,284 & 14,601 \\
\hline \multicolumn{3}{|l|}{ Transportation use } \\
\hline Personal (incl. gasoline) & 9,777 & 10,523 \\
\hline Mass transit & 283 & 275 \\
\hline Air transport & 805 & 824 \\
\hline \multicolumn{3}{|l|}{ Indirect influences ( $\mathrm{kg}$ ) } \\
\hline Housing & 6,290 & 5,096 \\
\hline Vehicles & 1,841 & 1,920 \\
\hline Food and beverages & 5,230 & 4,555 \\
\hline Entertainment & 1,398 & 1,321 \\
\hline Apparel and services & 946 & 662 \\
\hline Health care & 381 & 406 \\
\hline Other & 1,608 & 1,513 \\
\hline \multicolumn{3}{|l|}{ Total emissions (Mt) } \\
\hline Total direct & 25.15 & 26.22 \\
\hline Total indirect & 17.69 & 15.47 \\
\hline Total per household & 42.84 & 41.70 \\
\hline
\end{tabular}

Notes: Calculations include production, use, and disposal phases. Other includes pensions, finance costs, and education expenses. See appendix for full list of expenditure categories.

Source: Consumer Expenditure Survey (Sabelhaus and Harris 2008); author's calculations.

The aggregate data hide significant variation across Census regions. State level variation in the price of gasoline means that, for example, one dollar in 2002 translated to approximately $6.2 \mathrm{~kg}$ of GHG in the West and $6.8 \mathrm{~kg}$ in the South. Likewise, variation in the carbon intensity and retail price of electricity production means that one dollar spent in 2002 on electric utilities resulted in $6.5 \mathrm{~kg}$ of GHG in the Northeast and $11.7 \mathrm{~kg}$ in the Midwest. 
Using Eq. 1, I begin by analysing the univariate relationship between emissions and expenditures. I estimate the univariate model by GLM for three quantifications of emissions: total, direct, and indirect. I combine data from 1997 and 2002 using expenditures in real 2000 dollars, adjusting for inflation rates specific to each purchased commodity. The results are shown in Figure 1.

The elasticity $\varepsilon$ of energy equals the percent change in emissions for a 1 percent change in expenditures at the means. Direct energy intensity starts at low levels of expenditures accounts for twice as many emissions as indirect consumption, but grows slowly with expenditures. The relationship between indirect energy and expenditure is almost perfectly linear. Indirect emissions by households equals direct emissions at an expenditure of about $\$ 60,000$, at which point the average household emissions are above $50 \mathrm{Mt}$. For expenditures above that level, indirect energy demand from consumption is a more important source of emissions than are direct energy purchases.

I introduce additional explanatory variables using Eq. 2. I begin with a bivariate analysis, in which I model total household emissions as a function of expenditures and education. As educated households are on average wealthier and have greater income, I control for expenditures to compare households that consumed at a level around the population mean of $\$ 41,000$. There is a small but significant difference evident, with more educated households producing significantly fewer emissions at a given level of consumption. A marginal year of education for the household head is associated with approximately $-351 \mathrm{~kg} / \mathrm{yr}$ of GHG emissions for the household. Figure 1 shows the modelled relationship of household emissions to expenditures for four discreet levels of education. Only 40 percent of household heads in 2002 had completed college; if the remaining 60 percent were to spend two more years in school, e.g. to earn an associate degree or complete a baccalaureate, then emissions could, ceteris paribus, drop by as much as 46 million Mt per year, approximately 0.8 percent of total U.S. GHG emissions. While perhaps a small impact compared to the mammoth scale of population-wide emissions, this is the first evidence that consumption patterns of educated households may have less environmental impact per dollar than other households. 
Figure 1: Univariate regression of GHG emissions on expenditures, US 1997-2002
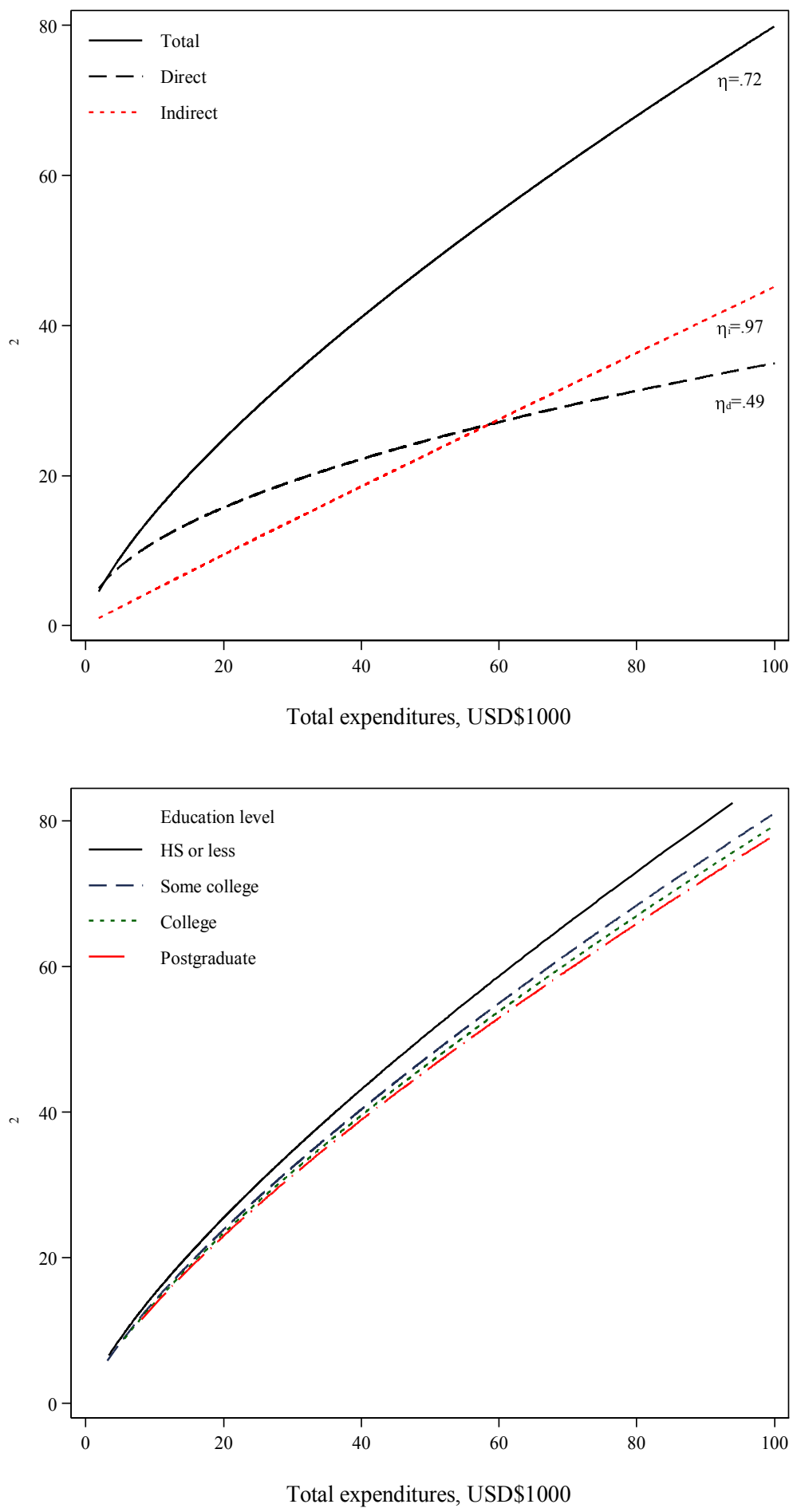

Source: Consumer Expenditure Survey (Sabelhaus and Harris 2008); Green Design Institute (CMU GDI 2008); author's calculations. 
From whence are the emissions savings accruing? In Figure 2, I present plots of predicted spending and total associated emissions on a variety of expenditure categories, sorted from greatest to least.

Figure 2: Emissions and expenses by category and education of household head, US 2002

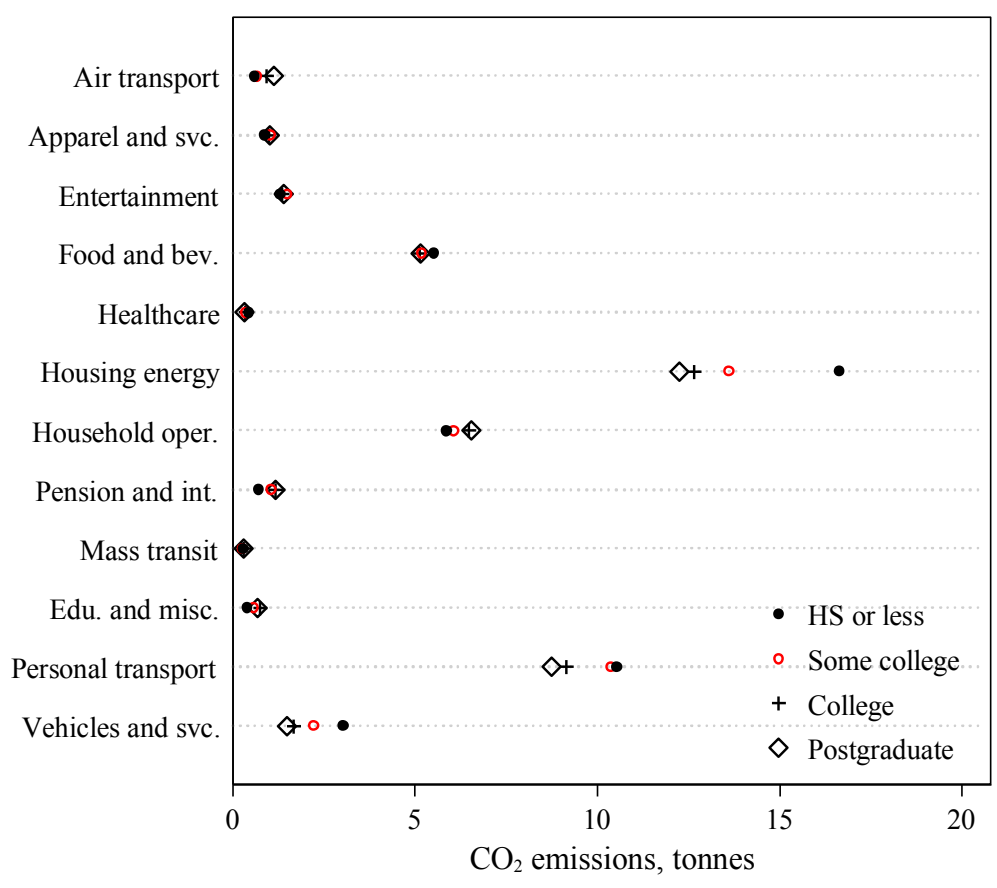

Mean real expenditure: 2000 US\$40,500

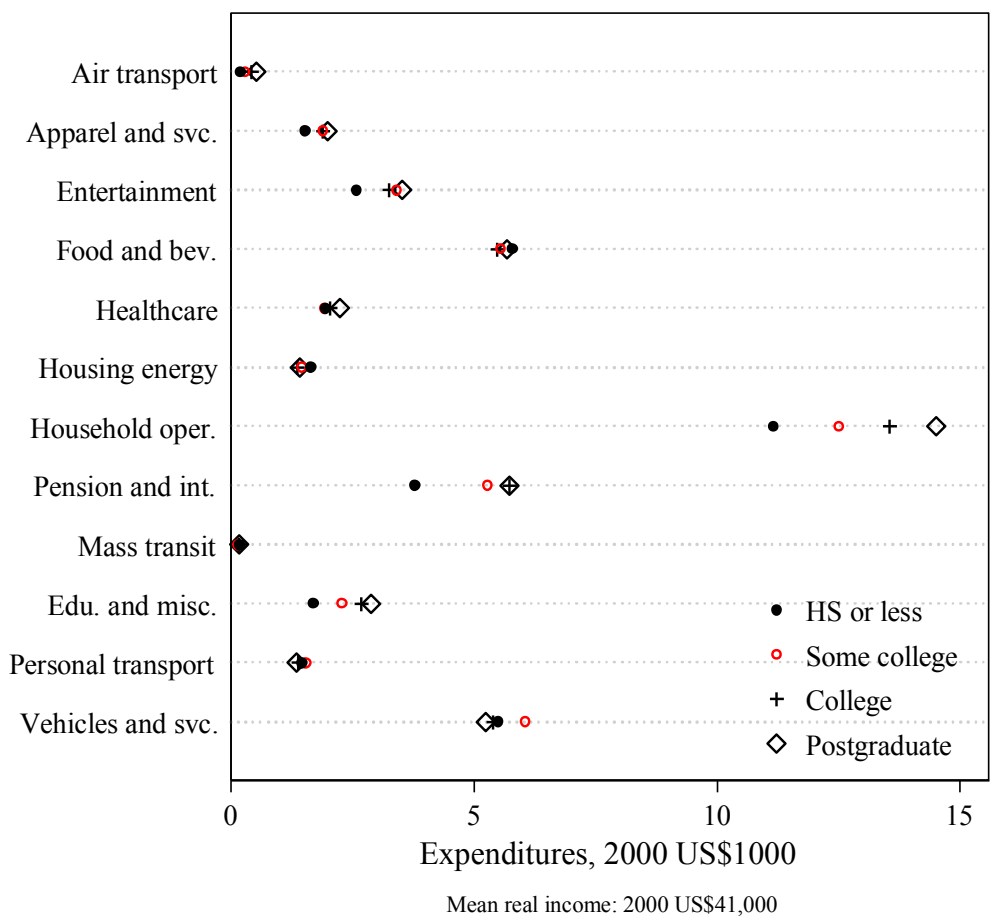

Source: Consumer Expenditure Survey (Sabelhaus and Harris 2008); Green Design Institute (CMU GDI 2008); author's calculations. 
Household operations (including housing costs) is the largest category of expenditures for most households each year. Housing costs diminished somewhat between 1997 and 2002 as a percentage of spending for all households except the least educated, controlling for income. The other categories of spending and emissions vary by education. Controlling for income, educated households spend much larger share of their income on pensions and other financial instruments, and a much smaller share on vehicles and related services. Educated households spend more on books and tuition, both relatively low impact activities. The important category of personal transport, which captures expenses on gasoline, is a smaller share of household expenses for more educated households.

The results translate directly into lower emissions for educated households, controlling for expenditures. While housing energy and personal transportation are the most important categories of emissions for all education groups, educated households' lower spending on these areas means their emissions are lower. They produce more emissions in several categories - food and beverages, for example, and their greater expenses on rented or owned housing means that they produce more emissions related to household operations and non-personal transportation method such as mass transit and flying. Educated households produce fewer emissions attributable to vehicle purchase and operation, which is a major source of emissions for households whose heads have no college experience.

\subsection{Multivariate Analysis}

Education may be correlated with other variables that may independently explain some of the variation in carbon intensity of consumption dollars. For example, more educated households may have fewer children, or be located in urban areas where the average household environmental impact is lower. To the bivariate model above I introduce additional demographic covariates that may explain household energy demand. The multivariate model is of the same form as Eq. 2, with additional covariates added to the model. The results are presented in Table 4.

The first model is a univariate regression of emissions on expenditures, discussed already above. The second column presents the bivariate regression results including education and holding expenditure constant. Educated household heads produce less GHG per dollar of expenditure: the marginal effect of one year of education is $-466 \mathrm{~kg}$ of $\mathrm{CO}_{2}$ per year emitted. This can add up quickly at the population level. Forty percent of U.S. household heads have not completed a college degree. If these households spent two additional years in school, total U.S. emissions would fall by 40.7 billion tonnes, without any reduction in household spending necessary. 
Table 4: Regression of household characteristics on CO2 emissions, US 1997-2002

\begin{tabular}{|c|c|c|c|c|}
\hline $\mathrm{CO} 2(\mathrm{~kg}, \log )=$ & (1) & (2) & (3) & (4) \\
\hline \multirow[t]{2}{*}{ Expenditure $(\$, \log )$} & $0.717 * * *$ & $0.740 * * *$ & $0.731 * * *$ & $0.682 * * *$ \\
\hline & {$[0.00743]$} & {$[0.00796]$} & [0.00976] & {$[0.00850]$} \\
\hline \multirow[t]{2}{*}{ Education (years) } & & $-0.0116 * * *$ & $-0.0119 * * *$ & $0.00406^{* * *}$ \\
\hline & & [0.00106] & [0.00107] & {$[0.000988]$} \\
\hline \multirow[t]{2}{*}{ Income $(\$, \log )$} & & & $0.00894 *$ & 0.00566 \\
\hline & & & [0.00439] & {$[0.00424]$} \\
\hline \multirow[t]{2}{*}{ \# Children in hhd } & & & & $0.0274 * * *$ \\
\hline & & & & {$[0.00265]$} \\
\hline \multirow[t]{2}{*}{ \# Adults in hhd } & & & & $0.0675 * * *$ \\
\hline & & & & {$[0.00357]$} \\
\hline \multirow[t]{2}{*}{ Age of head } & & & & $0.00100 * * *$ \\
\hline & & & & {$[0.000186]$} \\
\hline \multirow[t]{2}{*}{ Location (1=Rural) } & & & & $0.0650 * * *$ \\
\hline & & & & {$[0.00769]$} \\
\hline \multirow[t]{2}{*}{ Constant } & $3.108 * * *$ & $3.022 * * *$ & $3.028 * * *$ & $3.254 * * *$ \\
\hline & {$[0.0796]$} & {$[0.0806]$} & [0.0814] & {$[0.0708]$} \\
\hline$N$ & 12301 & 12153 & 12153 & 12153 \\
\hline AIC & 262315.8 & 259016.2 & 259006.1 & 257520.5 \\
\hline
\end{tabular}

Notes: Robust standard errors in brackets. Includes controls for survey/emissions year (not shown). ${ }^{*} \mathrm{p}<$ $0.05, * * \mathrm{p}<0.01, * * * \mathrm{p}<0.001$

Subsequent models introduce additional covariates in order to reduce the possibility that education is capturing the effects of unobserved variables. The introduction of income has little effect, net of actual spending. While in model 3 it is marginally significant, the effect disappears when adding demographic controls (model 4). The higher emissions of wealthy households is due to greater spending, not to spending in categories which produce greater emissions. In model 4, age and household size and composition (adults and children in the household) have important effects. Some of the effect of education, then, is related to differences in age and household size between households with relatively more and relatively less education. Household heads with some college or a completed 4-year degree are the youngest on average in the CES. As total household consumption has been demonstrated to grow during middle age, excluding the age term biases the effect of education. Likewise, more educated households tend to be smaller, and to have fewer children. Years of education remain highly significant, although the scale of the effect is greatly diminished. The marginal effect of education in this scenario is $-168.1 \mathrm{~kg}$ of $\mathrm{CO}_{2}$ per year per household, or approximately -14.3 billion kg across all households in 2002 . This effect would be equal in size to the annual GHG emissions of nearly 3 million personal vehicles. ${ }^{6}$

\footnotetext{
${ }^{6} 14.26$ billion $\mathrm{kg}$ of $\mathrm{CO}_{2}$ is equivalent to the emissions indirectly and directly generated by the gasoline purchased by $1,435,095$ households (average of 2.04 vehicles and 9.9 tonnes of $\mathrm{CO}_{2}$ e per household). This is roughly equivalent to the estimate of 5.1 tonnes/yr for the average passenger car by the U.S. Environmental Protection Agency, which also equates to nearly 3 million car-years.
} 
In general equilibrium, the results are more complicated; more education may translate to faster income growth, and correspondingly higher emissions. However, the wage returns to education may diminish as the average worker becomes more educated, and any treatment effect of education in terms of consumer habits may in fact become larger as those who have less propensity to self-select into education receive it. It is also possible that demographic characteristics of households are jointly determined with their education; this regression model cannot distinguish the direction of causality or determine which model should be preferred.

\section{Conclusion}

Fossil fuels are the backbone of the world economy, and have enabled most of the economic growth experienced since the 18th century. As long as fossil fuels continue to supply most of the world's energy, the carbon intensity of production and consumption are not likely to radically change (cf. Dyson 2005). Highly effective ways to reduce emissions include halting population growth or halting economic growth. Nations, however, are not desirous to reject growth and affluence for their populations, and thus interest in the role of demography in environmental impacts has grown alongside research adoption of alternative energy. Household size, mean age, and urban/rural location have been repeatedly demonstrated to have a significant effect on the elasticity of population growth and total emissions in an economy. Education also appears to have a significant effect on household emissions. More educated individuals earn higher incomes, but they also spend their income in ways that reduce the carbon intensity of every marginal dollar relative to other wealthy but less educated households. Household heads with college or greater education spend more on housing but less on energy utilities; more on airfare and mass transit, but less on gasoline.

Education is a way out of poverty, and has also played a major role in world development. Improving education in the developing world is a U.N. Millennium Development Goal, and developed nations also seek to expand access to higher education as a way to increase innovation. In the end, the greater environmental benefit of education, from the perspective of reducing carbon emissions and other adverse impacts, will likely be the enrichment of societies' capacity to innovate technologically and accelerate alternatives to fossil fuels for the energy needed to support economic growth. Inasmuch as we wish to reduce the environmental externalities of economic growth, we should hope to see that gains in education keep pace with economic growth. 


\section{References}

APTA - American Public Transit Association. 1999. "Public Transportation Fact Book." APTA - American Public Transit Association. 2004. "Public Transportation Fact Book."

Bin, S. and H. Dowlatabadi. 2005. "Consumer lifestyle approach to US energy use and the related $\mathrm{CO}_{2}$ emissions.” Energy Policy 33(2):197-208.

Bongaarts, J. 1992. "Population Growth and Global Warming." Population and Development Review 18(2):299-319.

CMU GDI - Carnegie Mellon University Green Design Institute. 2008. "EIOLCA Economic Input-Output Life Cycle Assessment.” Accessed 7-11-2013.

Cole, M. and E. Neumayer. 2005. "Examining the impact of demographic factors on air pollution." Population and Development Review 2(1):5-21.

Commoner, B. 1972. "A Bulletin Dialogue: on 'The Closing Circle'." Bulletin of the Atomic Scientists 28:17-56.

Dalton, M., B. O’Neill, A. Prskawetz, L. Jiang, and J. Pitkin. 2008. "Population aging and future carbon emissions in the United States." Energy Economics 30:642-675.

Desrochers, P. and C. Hoffbauer. 2009. "The PostWar Intellectual Roots of the Population Bomb.” The Electronic Journal of Sustainable Development 1(3):73-97.

Dyson, T. 2005. "On development, demography and climate change: the end of the world as we know it?" Population and environment 27(2):117-149.

Ehrlich, P. and J. Holdren. 1971. "Impact of population growth.” Science 171:1212-1217.

EPDC. 2005. "Window on the Future: 2025." Technical report, Education Policy and Data Center,. Washington, DC.

Golley, J., D. Meagher, and M. Xin. 2008. "Chinese household consumption, energy requirements and carbon emissions." in China's Dilemma: Economic Growth, the Environment and Climate Change, edited by L. Song and W.T.Woo. Asia Pacific Press, Brookings Institution Press and Social Sciences Academic Press, 2008.

Herendeen, R., C. Ford, and B. Hannon. 1981. "Energy cost of living, 1972â A ,S73." Energy 6:1433-1450.

Hertwich, E.G. and G.P. Peters. 2009. "Carbon footprint of nations: a global, trade-linked analysis.” Environmental science \& technology 43(16):6414-6420.

IPCC. 2008. "Climate Change 2007: Synthesis Report." Technical report, IPCC, Geneva, Switzerland.

Jones, C., D. Kammen, and D. McGrath. 2008. "Consumer-oriented Life Cycle Assessment of Food, Goods and Services." UC Berkeley: The Berkeley Institute of the Environment.

Kanemoto, K., M. Lenzen, and M. Geschke, A. 2011. "Building Eora: a Global Multiregion Input Output Model at High Country and Sector Resolution." Paper presented at the 19th International Input-Output Conference, Alexandria, VA, USA. 
KC, S., B. Barakat, A. Goujon, V. Skirbekk, W. Sanderson, and W. Lutz. 2010. "Projection of populations by level of educational attainment, age, and sex for 120 countries for 2005-2050." Demographic Research 22(15):383-472.

Lenzen, M. 1998. "Primary energy and greenhouse gases embodied in Australian final consumption: an input-output analysis." Energy Policy 26(6):495-506.

Lenzen, M., M.Wier, C. Cohen, H. Hayami, S. Pachauri, and R. Schaeffer. 2006. "A comparative multivariate analysis of household energy requirements in Australia, Brazil, Denmark, India and Japan." Energy 31:181-207.

MacKellar, F., W. Lutz, C. Prinz, and A. Goujon. 1995. "Population, households, and $\mathrm{CO}_{2}$ emissions." Population and Development Review 21(4):849-865.

Martinez-Zarzoso, I. 2008. "The Impact of Urbanization on $\mathrm{CO}_{2}$ Emissions: Evidence from Developing Countries.” Working Papers 2008.50, Fondazione Enrico Mattei.

O’Neill, B.C. and B.S. Chen. 2002. "Demographic Determinants of Household Energy Use in the United States." Population and Development Review 28:53-88.

O’Neill, B.C., M. Dalton, R. Fuchs, L. Jiang, S. Pachauri, and K. Zigovad. 2010. "Global demographic trends and future carbon emissions." Proceedings of the National Academy of Sciences of the United States of America 107(41):17,521-17,526.

Osborn, F. 1948. Our Plundered Planet. London: Faber and Faber.

Pachauri, S. 2004. "An analysis of cross-sectional variations in total household energy requirements in India using micro survey data." Energy Policy 32(15):1723-1735.

Pachauri, S. and D. Spreng. 2002. "Direct and indirect requirements of households in India." Energy Policy 30:511-523.

Pariakh, J. and V. Shukla. 1995. "Urbanization, energy use and greenhouse effects in economic development." Global Environmental Change 5(2):87-103.

Peters, G., R. Andrew, and J. Lennox. 2011. "Constructing an environmentally-extended Multi-Region Input-Output table using the GTAP database." Economic Systems Research 23(2):131-152.

Reinders, A., K. Vringer, and K. Blok. 2003. "The direct and indirect energy requirement of households in the European Union.” Energy Policy 31:139-S153.

Robertson, T. 2012. The Malthusian Moment: Global Population Growth and the Birth of American Environmentalism. Rutgers University Press.

Sabelhaus, J. and Harris, E. 2008. "Consumer expenditure survey, family-level extracts." Electronic resource. Accessed 07/01/2013 from http://www.nber.org/data/ces_cbo.html.

Shammin, M., R. Herendeen, M. Hanson, and E. Wilson. 2010. "A multivariate analysis of the energy intensity of sprawl versus compact living in the U.S. for 2003." Ecological Economics 69:2363-2373.

USDOC ESA - U.S. Department of Commerce, Economics and Statistics Administration. 2010. "U.S. carbon dioxide emissions and intensities over time: a detailed accounting of industries, government and households." 
USDOE EIA - U.S. Department of Energy, Energy Information Administration. 2013a. "Form EIA-1605: Voluntary Reporting of Greenhouse Gases (historical series)."

USDOE EIA - U.S. Department of Energy, Energy Information Administration. 2013b. "Form EIA-826: Monthly Electric Utility Sales and Revenue Report with State Distributions (historical series)."

USDOE EIA - U.S. Department of Energy, Energy Information Administration. 2013c. "State Energy Data System (historical series)."

USDOE EIA - U.S. Department of Energy, Energy Information Administration. 2004. "Unit Conversions, Emissions Factors, and Other Reference Data."

USDOE EIA - U.S. Department of Energy, Energy Information Administration and Thomson Reuters. 2013. "Annual average energy spot prices (historical series)."

USDOT RITA - U.S. Department of Transportation, Research and Innovative Technology Administration. 2013. "Form 41: Air Carrier Financial Reports (historical series)."

Vogt, W. 1948. The Road to Survival. New York: Sloane Associates.

Weber, C. and H.S. Matthews. 2007. "Quantifying the global and distributional aspects of American household carbon footprint.” Ecological Economics 66:379-391.

Weber, C. and A. Perrels. 2000. "Modelling lifestyle effects on energy demand and related emissions." Energy Policy 28:549-566.

Wei, Y.M., L.C. Liu, Y. Fan, and G.Wu. 2007. "The impact of lifestyle on energy use and $\mathrm{CO}_{2}$ emission: an empirical analysis of China's residents.” Energy Policy 35:247-257.

Wiedmann, T. 2009. "A review of recent multi-region input-output models used for consumption-based emission and resource accounting." Ecological Economics 69(2):211222.

Zagheni, E. 2011. "The Leverage of Demographic Dynamics on Carbon Dioxide Emissions: Does Age Structure Matter?” Demography 48(1):371-399. 


\section{Appendix}

Table 5: Carbon intensity of direct energy goods, US 1997-2002

\begin{tabular}{lccrrrr}
\hline & $\begin{array}{c}\text { Carbon } \\
\text { content }\end{array}$ & Price & GHG $(\mathrm{kg} / \$)$ & Price & GHG $(\mathrm{kg} / \$)$ \\
\cline { 2 - 7 } & (see & & & & \\
Electricity & notes) & 8.43 & 8.15 & 8.44 & 8.01 \\
Natural Gas & 116.39 & 11.3 & 4.67 & 12.4 & 4.26 \\
Gasoline & 154.91 & 9.81 & 7.16 & 10.69 & 6.57 \\
Oil/other home fuel & 159.66 & 7.45 & 9.72 & 8.6 & 8.42 \\
Jet fuel/kerosene & 154.69 & 4.51 & 15.45 & 5.34 & 13.14 \\
\hline
\end{tabular}

Notes: Prices for electricity in US cents/kWh; other prices in US dollars/mBtu. GHG content for electricity in $\mathrm{mt} / \mathrm{mWh}$; other GHG content in $\mathrm{lb} / \mathrm{mBtu}$. GHG content of electricity in $1997=0.687$ and 2002=0.676. National averages shown.

Source: Electricity prices by state from USDOE EIA 2013b; other prices except jet fuel by state from USDOE EIA 2013c; prices for jet fuel/kerosene from USDOE EIA and Thompson Reuters 2013; electricity CO2 content by state from USDOE EIA 2013a; other CO2 content from USDOE EIA 2004.

Table 6: Detailed expenditure categories, US 1997-2002

\begin{tabular}{|c|c|}
\hline Summary category & Detailed categories \\
\hline Home energy & $\begin{array}{l}\text { electricity (direct+indirect), natural gas (direct+indirect), } \\
\text { other home fuels (direct+indirect). }\end{array}$ \\
\hline Personal transport & gasoline (direct+indirect), tolls \\
\hline Mass transit & mass transit (direct + indirect), other transit (direct + indirect) \\
\hline Air transportation & airfares (direct+indirect) \\
\hline Housing operation & $\begin{array}{l}\text { home rent (or imputed rent), vacation rentals, furniture, } \\
\text { housing supplies, water, telephone service, domestic } \\
\text { workers }\end{array}$ \\
\hline Food and beverages & $\begin{array}{l}\text { food at home, food provided by employer, food outside the } \\
\text { home, alcohol for home consumption }\end{array}$ \\
\hline Apparel and allied & $\begin{array}{l}\text { clothing, tailors, jewelry, toiletry products, health and } \\
\text { beauty services }\end{array}$ \\
\hline Entertainment & $\begin{array}{l}\text { tobacco, alcohol consumed outside home, books, } \\
\text { periodicals, sports and recreation, gambling, other } \\
\text { recreation }\end{array}$ \\
\hline Health care & $\begin{array}{l}\text { medicines, medical devices, health insurance, hospital } \\
\text { visits, nursing home, doctor visits }\end{array}$ \\
\hline Vehicles & $\begin{array}{l}\text { autos (new or used, purchase or lease), auto parts and } \\
\text { accessories, auto services, car insurance }\end{array}$ \\
\hline Interest and pensions & car loan interest, other interest, pension contributions \\
\hline Other & $\begin{array}{l}\text { professional services (lawyers, accountants), life insurance, } \\
\text { education expenses, charitable contributions. }\end{array}$ \\
\hline
\end{tabular}

Notes: Mass transit and airfare include a portion of direct energy goods, calculated as the product of (passenger revenue/total revenue)*(fuel expenses/total expenses)*(carbon intensity of fuel mix).

Source: Share of mass transit and air transportation spending attributable to fuel from APTA 1999, APTA 2004, and USDOT RITA 2013. For lower-level spending codes in the CES, see Sabelhaus and Harris. (2000) 


\section{VIENNA INSTITUTE OF DEMOGRAPHY}

\section{Working Papers}

Winkler-Dworak, Maria and Heiner Kaden, The Longevity of Academicians: Evidence from the Saxonian Academy of Sciences and Humanities in Leipzig, VID Working Paper 03/2013.

Feichtinger, Gustav, Alexia Prskawetz, Andrea Seidl, Christa Simon and Stefan Wrzaczek, Do Egalitarian Societies Boost Fertility?, VID Working Paper 02/2013.

Muttarak, Raya, Is it (dis)Advantageous to Have Mixed Parentage? Exploring Education \& Work Characteristics of Children of Interethnic Unions in Britain?, VID Working Paper 01/2013.

Testa, Maria Rita and Stuart Basten, Have Lifetime Fertility Intentions Declined During the "Great Recession"?, VID Working Paper 09/2012.

Buber, Isabella, Ralina Panova, and Jürgen Dorbritz, Fertility Intentions of Highly Educated Men and Women and the Rush Hour of Life, VID Working Paper 08/2012.

Testa, Maria Rita, Laura Cavalli, and Alessandro Rosina, The Decision of Whether to Have a Child: Does Couple Disagreement Matter?, VID Working Paper 07/2012.

Kuhn, Michael and Klaus Prettner, Growth and Welfare Effects of Health Care in Knowledge Based Economies, VID Working Paper 06/2012.

Sander, Nikola and Martin Bell, Age, Period and Cohort Effects on Migration of the Baby Boomers in Australia, VID Working Paper 05/2012.

Grafeneder-Weissteiner, Theresa, Ingrid Kubin, Klaus Prettner, Alexia Prskawetz, and Stefan Wrzaczek, Coping with Inefficiencies in a New Economic Geography Model, VID Working Paper 04/2012.

Goujon, Anne, Éric Caron Malenfant, and Vegard Skirbekk, Towards a Catholic North America? Projections of Religion in Canada and the US beyond the Mid-21st Century, VID Working Paper 03/2012.

Di Giulio, Paola, Christoph Bühler, Andreas Ette, Romina Fraboni, and Kerstin Ruckdeschel, Social Capital and Fertility Intentions: The Case of Italy, Bulgaria, and West Germany, VID Working Paper 02/2012.

Abel, Guy J., Estimating Global Migration Flow Tables Using Place of Birth Data, VID Working Paper 01/2012.

The Vienna Institute of Demography Working Paper Series receives only limited review. Views or opinions expressed herein are entirely those of the authors. 